\title{
The missing link between maintenance contracts and flexible asset management
}

\author{
Salla Marttonen \\ Doctoral student \\ Department of Industrial Management \\ Lappeenranta University of Technology \\ P.O. Box 20, FIN-53851 Lappeenranta, Finland \\ salla.marttonen@lut.fi \\ Sari Viskari \\ Doctoral student \\ Department of Industrial Management \\ Lappeenranta University of Technology \\ P.O. Box 20, FIN-53851 Lappeenranta, Finland \\ sari.viskari@lut.fi \\ Timo Kärri \\ Professor \\ Department of Industrial Management \\ Lappeenranta University of Technology \\ P.O. Box 20, FIN-53851 Lappeenranta, Finland \\ timo.karri@lut.fi
}

\begin{abstract}
The paper shows how additional value can be created in maintenance collaboration through integrating the features of flexible asset management into maintenance contracts. We expand the traditional typology of maintenance contracts and introduce a new contract type, flexible asset management contracts. Also value sharing in the new contract type is discussed. Our logic for sharing the value is based on reaching for win-win situations in industrial maintenance collaboration. Finally, we present scenarios which prove that significant financial benefit can be achieved through adopting these novel contracts. In the dynamic and challenging operating conditions of the present, companies should actively search for this kind of possibilities for closer collaboration with their customers and suppliers.
\end{abstract}


Keywords: maintenance; contracts; flexible asset management; fixed assets; working capital; typology; value sharing; pricing; win-win; customer; service provider.

\section{Acknowledgements:}

The authors wish to thank the anonymous reviewers for their valuable time and feedback. Their advice has truly improved the final paper.

\section{Introduction}

This paper addresses combining the traditional understanding of maintenance contracts with flexible asset management thinking. Competition has become tight and globalised, and the number of outsourcings has increased. This has enhanced the collaboration between customer and supplier companies (Kroes and Ghosh, 2009; Yazici, 2012). Industrial maintenance service providers are forced to pursue higher profits for themselves and additional benefits for their customers. Therefore, maintenance companies are searching for novel contracts and services to offer (Martin, 1997; Wang, 2010). Companies can improve their performance through sharing more information with their supply chain partners (see e.g. Fantazy et al., 2011; Magnan et al., 2011). At the same time, companies must increase their adaptability in order to survive in the ever-increasing dynamism of the operating conditions (More and Babu, 2011). This dynamism can be managed through strategic partnerships (Raut et al., 2012). One way of accomplishing these partnerships and hence adaptability is through flexible asset management (Gibson, 2000; Marttonen et al., 2011; Navarro, 2009; Ojanen et al., 2012; Sawhney et al., 2009).

Extensive collaboration in maintenance networks calls for new models and methods (Ahonen et al., 2010). So far, flexible asset management has not been considered from the maintenance contract perspective. By adopting this view, additional asset management services can be attached to the actual maintenance contract. The value sharing of these additional services has not been studied before, either.

The goal of this study is to demonstrate the creation of additional value in maintenance collaboration by combining the research areas of flexible 
asset management and maintenance contracts. Our research questions are the following:

- How can the principles of flexible asset management influence the traditional understanding of the typology of maintenance contracts?

- What are the strengths and weaknesses offlexible asset management contracts compared with traditional contract types?

- How should the value be shared in flexible asset management contracts in order to reach win-win situations in maintenance collaboration?

Our contribution to the existing literature is expanding the traditional typology of maintenance contracts. We also discuss the benefits of contracts with flexible asset management services, and present how the value of the additional services of these contracts can be shared in favour of win-win situations. The value sharing of the actual maintenance work is not addressed.

The structure of the paper is as follows. After the introduction, section 2 discusses the literature of maintenance contracts and flexible asset management. In section 3, the research setting is presented. Next, a novel typology of maintenance contracts is introduced in section 4 . In section 5 we address the matter of value sharing in flexible asset management contracts. Section 6 offers scenarios on flexible asset management contracts in case companies, and summarises how companies can exploit the link between maintenance contracts and flexible asset management. The article ends with conclusions.

\section{Literature review}

\subsection{Maintenance contracts}

The tightened competition and the emergence of outsourcings have caused many companies to increase collaboration with their customers and suppliers (Kroes and Ghosh, 2009; Yazici, 2012). Maintenance serviceproviding companies are looking for new types of contracts to improve their profitability and provide additional benefits for their customers (Martin, 1997). Wang (2010) states that service providers can pursue higher profits 
by sharing the customer's risks. We point out that previous literature considers mostly the perspective of the customer, while optimisation from the service provider's point of view is unusual. Previous research shows that inter-organisational information sharing improves the performance in supply chains (e.g. Fantazy et al., 2011; Magnan et al., 2011). Holmström et al. (2010) state that information sharing enables new forms of collaboration - for example customers may outsource the ownership of physical assets.

We introduce a new type of maintenance contracts, the flexible asset management contract. Essentially, the theoretical foundations of this paper are in the traditional agency theory (see e.g. Grossman and Hart, 1983; Hart and Holmström, 1987). However, we do not discuss the agency theory in detail in this paper. Instead, we focus on a more specific topic, contracts in the maintenance business. Accordingly, our reasoning is based on the explicit typology of maintenance contracts presented by Martin (1997). This widely cited typology includes three contract types: work package contracts, performance contracts, and facilitator contracts, also called lease contracts. In work package contracts, the service provider simply performs the tasks given by the customer. In performance contracts the service provider is typically also responsible for maintenance planning and organisation. The service company then agrees to provide the customer with a specific level of asset availability. Compared to work package contracts, performance contracts are more complex and require more trust between the contracting companies. The final contract type in Martin's typology, the lease contract, means that the service provider owns the assets to be maintained. Thus the customer pays for using the assets, and the service provider is tied to their ownership. From the perspective of flexible asset management, this means inherent inflexibility. For example, the main benefit of lease contracts is usually seen to be the chance of decreasing the risks of the customer (e.g. Pongpech et al., 2006), although this may happen at the expense of the service provider.

The viewpoint introduced for example by Teece (1988) assumes that each contracting party acts opportunistically. Of course, there is always a risk that opportunism incurs surprising losses for one or both of the companies (Vining and Globerman, 1999). As a solution, de Jong and Smit (2012) have introduced collaborative contracts, in which the objectives of 
the contracting companies are congruent. By implementing flexible asset management contracts, these ideal collaborative contracts can be made more approachable.

The liabilities in maintenance contracts have been discussed in previous literature. For example, the issue of who accounts for the success of maintenance in outsourcing situations has been studied (e.g. Hui and Tsang, 2006; Levery, 1998). Multiple research gaps can be found in the traditional contract typologies, however. This is also acknowledged by Ahonen et al. (2010), who claim that novel tools are needed to promote the increasing collaboration in maintenance service networks. This point, although on a more general level, is also recognized by MacCarthy and Jayarathne (2012). Markeset and Kumar (2005) state that it has become more common for the service provider, not the customer, to own the physical assets. What remains quite unexplored, however, are the profitability impacts of the assets being included in the service provider's balance sheet. Panesar and Markeset (2008) state that the conditions of the customer - service provider relationship must encourage the service provider to improve the performance of the customer actively. In general, the existing maintenance contract types have not succeeded in doing that. Jackson and Pascual (2008) have introduced a model for maintenance service pricing, but models for sharing the value of the accessory flexible asset management services in maintenance contracts do not exist. This is where we contribute to the discussion.

\subsection{Flexible asset management}

Today, dynamism is an essential part of doing business. In order to remain profitable, companies should somehow adapt to different operating conditions (More and Babu, 2011). Raut et al. (2012) emphasise the role of strategic partnerships in controlling dynamism. One way of advancing this is flexible asset management (Gibson, 2000; Navarro, 2009), where the amount of assets in a company's balance sheet should follow the progression of changing demand. Considering a broader discussion, the importance of asset management for company profitability has been identified by several researchers (e.g. Aoudia et al., 2008; Lin et al., 2007; Tam and Price, 2008). Sawhney et al. (2009) point out that flexible asset 
management is also significant in striving for a lean business philosophy. Companies have also recognised the importance of flexible asset management: in an international survey conducted by the European Federation of National Maintenance Societies (2011), 67\% of the respondents thought that the flexibility of production assets is either significant or very significant.

Previous literature has studied how to make fixed assets more flexible (e.g. Kärri, 2007). In fact, flexible asset management has traditionally mostly concerned fixed assets (Komonen, 2010) and long-term capital (Chiou et al., 2006). However, also current assets should be taken into account, for example by managing the company's operational working capital. This is defined as inventories plus accounts receivable less accounts payable. In the maintenance business, the main drivers of working capital are spare part stocks and payment terms. Ojanen et al. (2012) highlight the importance of working capital in flexible asset management. Working capital management can have a significant impact on both company profitability and liquidity (Protopappa-Sieke and Seifert, 2011; Talha et al., 2010). Grosse-Ruyken et al. (2011) and Randall and Farris (2009) emphasise the importance of managing working capital together with the supply chain partners. In inter-organisational maintenance collaboration, the role of working capital management is particularly important, as the amount of fixed assets is generally low in maintenance service companies (Marttonen et al., 2011; 2012). So far, working capital management has not been addressed very often in previous academic literature (Viskari et al., 2011).

In order to make the principles of flexible asset management more explicit, we present the flexible asset management model (the FAM-model) first introduced by Marttonen et al. (2012). The FAM-model combines aspects of asset management, profitability and financing. The model has been created through modifying the conventional formulas of the return on investment and the cost of capital. We use this model in our scenarios in section 6. The FAM-model can be presented as:

$$
R O I=\frac{E B I T D A \%-\left(F A \% * \frac{1}{B-1}\right)}{\frac{C C C}{365}+\frac{r}{365}+F A \%}=\frac{i_{D} * D+i_{E} * E}{D+E},
$$


where $R O I$

EBITDA\%

$F A \%$

$B$

$C C C$

$r$

$i D$

$i_{E}$

$D$

E is the company's return on investment, is the proportion of the profit margin to the net sales, is the proportion of the fixed assets to the net sales, is the average depreciation time in years, is the cycle time of operational working capital in days,

is the residual which consists of other current assets and other current liabilities, is the interest rate of company debt financing, is the company return on equity, is the amount of long-term debt in the company balance sheet,

is the amount of equity in the company balance sheet.

The FAM-model perceives the ROI as a function of both fixed $(F A \%, B)$ and current asset management $(C C C, r)$. In addition, from the perspective of the return on equity, the model can be presented as

$$
i_{E}=\frac{E B I T D A \%-\left(F A \% * \frac{1}{B-1}\right)}{\frac{C C C}{365}+\frac{r}{365}+F A \%} *\left(1+\frac{D}{E}\right)-i_{D} * \frac{D}{E} .
$$

In equation (2) the principle of financial leverage is evident: by increasing the share of debt in its balance sheet, a company can improve its return on equity. Financial leverage, as well as the FAM-model, will be readdressed in the following sections.

\section{Research setting}

The new type of maintenance contracts, flexible asset management contracts introduced in this study are based on previous literature. We also address the logic for value sharing in these new contracts. It should be noted that the value sharing of the maintenance work itself is not discussed in this paper. Instead, we focus on sharing the value of the additional services of flexible asset management contracts. First, we introduce a theory of value sharing in the contracts, and then the theory is refined through a case study. Dubois and Araujo (2007) state that case research contributes extensively 
to the research of purchasing and supply management, and according to Yin (2009), case research contributes to situations where "how" or "why" questions are studied, and when a deep understanding is needed of a certain phenomenon. These conditions are fulfilled in our research to a great extent. The research stages of the paper are presented in figure 1.

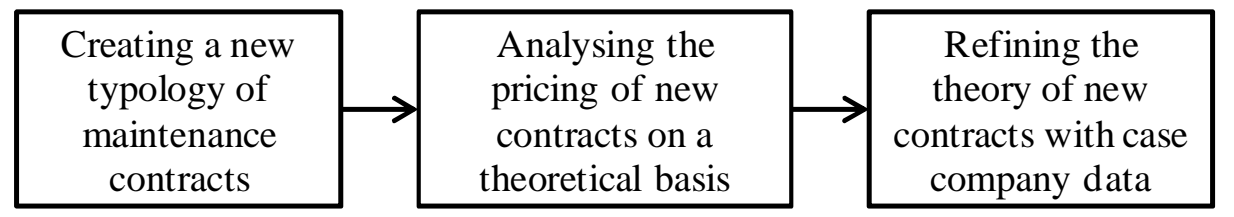

Figure 1 The exploratory phasing of the paper

The case companies chosen for this study were Metsä Fibre Oy and Botnia Mill Service Oy. Metsä Fibre is a well-known Finnish producer of pulp. Botnia Mill Service, on the other hand, provides industrial maintenance services almost exclusively for Metsä Fibre. Botnia Mill Service has been founded from the internal maintenance department of Metsä Fibre, and it is also partially owned by its customer. This means that the collaboration between these two companies is close and long-term. Hence, it is particularly justified to study the introduction of a very collaborative contract type between these companies, compared to average customerservice provider relationships. In addition, Metsä Fibre represents the pulp industry, which is capital intensive. Asset management collaboration with a service company that carries a light balance sheet can be assumed to be fruitful.

The case companies were studied through their financial statement data. The financial statements of year 2010 were used, as data from more recent years was not available. Using data from just one year can be considered reasonable, as we show how the new maintenance contract type can have an impact on the current profitability of the case companies. In 2010, Metsä Fibre had a net sales of 1,365M€, and a balance sheet total of 996M€. In Botnia Mill Service, the net sales were 54M€ and the balance sheet total 20M€. The data of the case companies was used to create two different scenarios, which illuminate the sharing of the value of the additional services related to the flexible asset management contracts. 


\section{Combining flexible asset management and maintenance contracts}

Here we extend the typology of maintenance contracts by combining flexible asset management thinking with the typology of maintenance contracts presented by Martin (1997). We have incorporated some characteristics of flexible asset management thinking into the new contract type. These are:

- Ownership of the fixed assets that the contract concerns

- Ownership of the spare part stocks related to the contract

- The impact of the payment terms on the profitability of the contract

- The impact of financial leverage on the profitability of the contract

The first two points about the ownership of assets and spare parts have already been discussed in the literature in the connection of pursuance of lease contracts. However, lease contracts tend to determine the service provider as the owner of the assets and spare parts. In our typology we strive for more flexibility, and thus in flexible asset management contracts the ownership can also be shared between the customer and the service provider. The third point concerns payment terms, which are present also in all traditional contract types. However, we would like to highlight the potential importance of the payment term decisions in the profitability of the contract. After all, operating with short payment times is a significant part of all lean business models. Finally, the impact of financial leverage should not be neglected when creating maintenance contracts. Gaining financial leverage can boost the profitability of the contract. For example, if a company chooses to carry additional assets in its balance sheet, financing these assets with debt can improve the company's return on equity.

The characteristics discussed above are the main features of flexible asset management contracts. The relation of the flexible asset management contract to the traditional contract types is presented in figure 2. The dimensions used in figure 2 are the amount of trust required from the customer-service provider relationship, and the complexity of the contract. Here we assume that the complexity of the contract type has a positive correlation with the costs incurred by creating and maintaining the contract. 


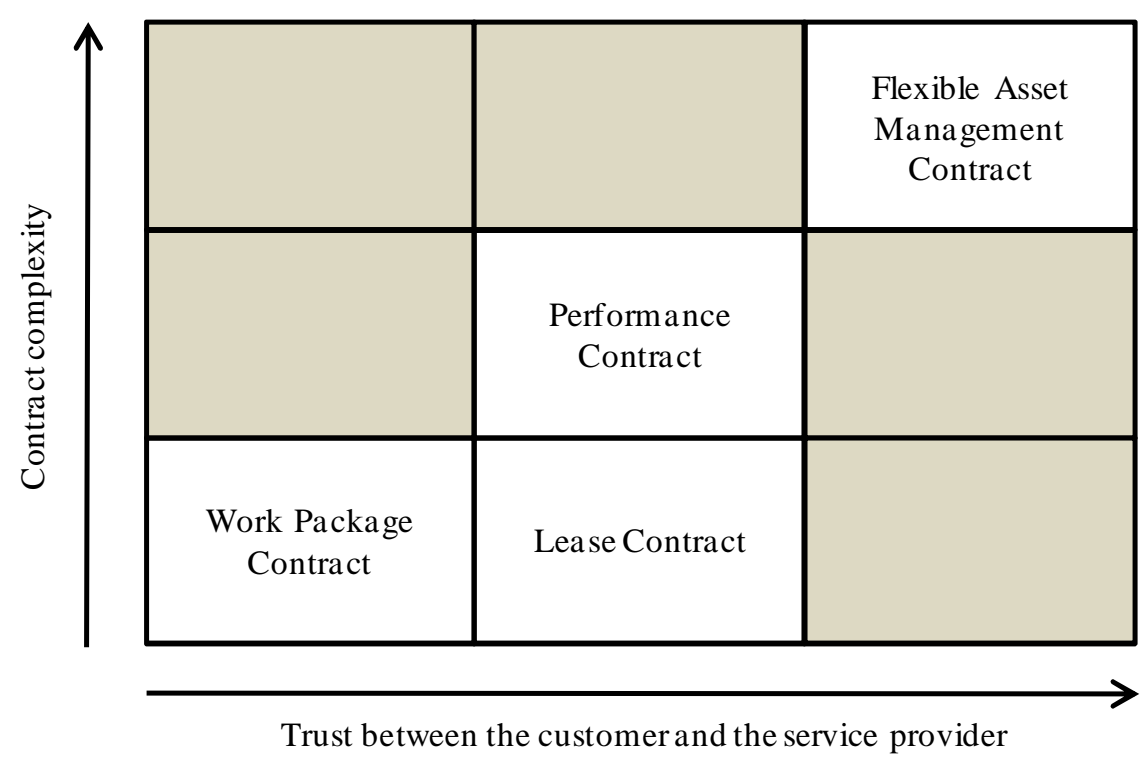

Figure 2 The novel typology of maintenance contracts

An increase in the complexity of the contract type creates an increase in the potential benefits to be reached through the contract; in work package contracts the benefit is caused by the ability of the service provider to execute maintenance work tasks in a more cost-effective way, compared to the customer. In typical performance contracts the potential benefit is extended to include also the superior ability of the service provider to conduct maintenance planning and organising. In lease contracts the customer is usually released from the risk of owning the assets. However, we argue that the potential benefits of the lease contract are actually quite low. This is because the benefits can be great for the customer, but not so great for the service provider. In lease contracts the risks induced by the ownership of the assets are simply transferred from the customer to the service provider, which is not the optimal solution, at least from the point of view of maintenance collaboration.

In order to maximise the collaboration benefit and to create a win-win situation, the risks should be balanced between the partners in flexible asset management contracts. We can conclude that, compared to traditional maintenance contracts, flexible asset management contracts call for more trust between the contracting parties. In addition, due to different terms of ownership, they are more complex, and hence more costly than the other 
three contract types presented in figure 2. On the other hand, also the potential benefits are higher in flexible asset management contracts than in other types of contracts. This new type of maintenance contracts can create additional value for both the customers and the service providers through additional services, like asset ownership. Before making profit, however, the value created by the contract has to be shared between the contracting partners.

\section{Value sharing in flexible asset management contracts}

Here we address sharing the value created by the additional flexible asset management services discussed in the previous sections. The first challenge in the value sharing of a flexible asset management contract is fixed asset ownership. In the FAM-model (equation 1) it can be seen that the amount of fixed assets compared with the amount of company net sales (the $F A \%$ ) has an impact on the ROI. Depending on the other parameters, as well as the initial level of the $F A \%$, the change of the ROI caused by adjusting the $F A \%$ varies across companies. In order to share the value of the flexible asset management contracts, we need the variable $\triangle R O I_{F A \%}$, defined as

$$
\Delta R O I_{F A \%}=\operatorname{ROI}\left(F A \%_{2}\right)-R O I\left(F A \%_{1}\right),
$$

where $\triangle R O I_{F A} \% \quad$ is the change of the $R O I$ caused by an adjustment in the amount of fixed assets,

$R O I(F A \% 2) \quad$ is the $R O I$ calculated with the adjusted $F A \%$,

$R O I\left(F A \%_{1}\right) \quad$ is the $R O I$ calculated with the initial $F A \%$.

In order to examine the impact of the $F A \%$ on the profitability in monetary terms, we must take the amount of invested capital into account. In the ROI, this invested capital consists of long-term debt and equity. The monetary change implies how much the profits should change for the company to end up on the same level of the $R O I(F A \% 2)$, even though the amount of fixed assets remained unchanged.

When asset ownership is shifted from one company to another, it is possible that profitability decreases for the company that takes the asset into its balance sheet (company A), while profitability increases for the firm that gives up the asset (company B). In this situation, a fair value sharing calls 
for pricing this "asset ownership service". The price should be set somewhere between the losses of company A and the profits of company B. This way, both companies should gain from the arrangement. This logic of value sharing is presented in equation (4).

$$
-\Delta R O I_{A} *\left(D_{A}+E_{A}\right)<p<\Delta R O I_{B} *\left(D_{B}+E_{B}\right),
$$

where $p$ is the price charged by company A from company $\mathrm{B}$ for taking the ownership of the asset,

$\triangle R O I_{A}$ is the decrease of the $R O I$ caused by the increased fixed assets in company A,

$\triangle R O I_{B} \quad$ is the increase of the $R O I$ caused by the decreased fixed assets in company B,

$D_{A} \quad$ is the amount of long-term debt in company A,

$D_{B} \quad$ is the amount of long-term debt in company B,

$E_{A} \quad$ is the amount of equity in company A,

$E_{B} \quad$ is the amount of equity in company B.

Depending on the context, the scale of the segment for an agreeable service price described by equation (4) can vary substantially. The larger the segment, the more untapped financial benefit is included in taking the asset ownership arrangements as a part of the maintenance contract. It is of course possible that an agreeable price does not exist, meaning that there is no value to be shared. This is the case when the decreased profits of company $\mathrm{A}$ are greater than the increased profits of company $\mathrm{B}$, or when the profits decrease for both companies. When an agreeable service price cannot be detected, this service of asset ownership should be left out of the contract. It is also possible that both companies will reach an increase in their profitability through shifting assets from company B to company A. In this case the role of the service price is to share the profits between the two companies, using a logic which the companies have agreed on.

Now we move on to discuss value sharing of spare part stock ownership and payment term alterations. These two aspects can be addressed together, as they both impact on the cycle time of operational working capital, the $C C C$, in the FAM-model (equation 1). The logic of sharing the value remains the same as above in the discussion about asset ownership. Once again we start by defining the impact of the agreement on the company $R O I$ : 


$$
\triangle R O I_{C C C}=R O I\left(C C C_{2}\right)-R O I\left(C C C_{1}\right),
$$

where $\triangle R O I_{C C C} \quad$ is the change of the $R O I$ caused by an adjustment in the cycle time of operational working capital,

$R O I\left(C C C_{2}\right)$ is the $R O I$ calculated with the adjusted $C C C$, $R O I\left(C C C_{l}\right)$ is the $R O I$ calculated with the initial $C C C$.

From this point on, the process of sharing the value is not unlike the process described for asset ownership agreements. Equation (4) is also suitable for pricing spare part stock ownership and payment term alterations. Again, the size of the segment for an agreeable service price determines the amount of potential financial benefits present in including the spare parts and payment terms in the maintenance contract.

Finally, we discuss using financial leverage to improve the profitability of a maintenance contract. In the previous paragraphs the profitability changes were analysed through the ROI. However, the impacts of the financial leverage are better to explicate through the return on equity, $i E$. When a company accepts additional assets, spare part stocks, or disadvantageous payment terms in its balance sheet, the financing of these items has to be organised. Presented simply, additional balance sheet items can be financed with either debt or equity financing. When deciding whether to use equity or debt, the impact of financial leverage on contract profitability should be studied.

For the sake of simplicity, this analysis focuses on the financial leverage of company A, the company that takes additional items to its balance sheet. The financial leverage of company B is left for further research, since adjusting the company financing would be more complicated when giving balance sheet items away. In order to include the impact of financial leverage in the logic of sharing value, we introduce variable $\Delta i_{E A}$ :

$$
\Delta i_{E A}=i_{E A 2}-i_{E A 1},
$$

where $\Delta i_{E A}$

is the change of the $i E$ caused by an adjustment in the capital structure of the company,

$i_{E A 2} \quad$ is the $i_{E}$ calculated with the adjusted capital structure, $i_{E A l} \quad$ is the $i_{E}$ calculated with the initial capital structure. 
Equation (4) must now be altered to take the monetary impact of the financial leverage into account. This can be done by including the $\Delta i_{E A}$ as well as the amount of equity in company $\mathrm{A}$ in the equation:

$$
-\Delta R O I_{A} *\left(D_{A}+E_{A}\right)+\Delta i_{E A} * E_{A}<p<\Delta R O I_{B} *\left(D_{B}+E_{B}\right) .
$$

Equation (7) concludes our theoretical reasoning about sharing the value of additional flexible asset management services. Next we demonstrate the benefits of these contracts through a case study.

\section{Findings of the case study}

\subsection{Scenarios on flexible asset management contracts}

In this subsection we illuminate how the case companies could benefit from adopting flexible asset management contracts. Figure 3 summarizes the data collected from the financial statements of the case companies.

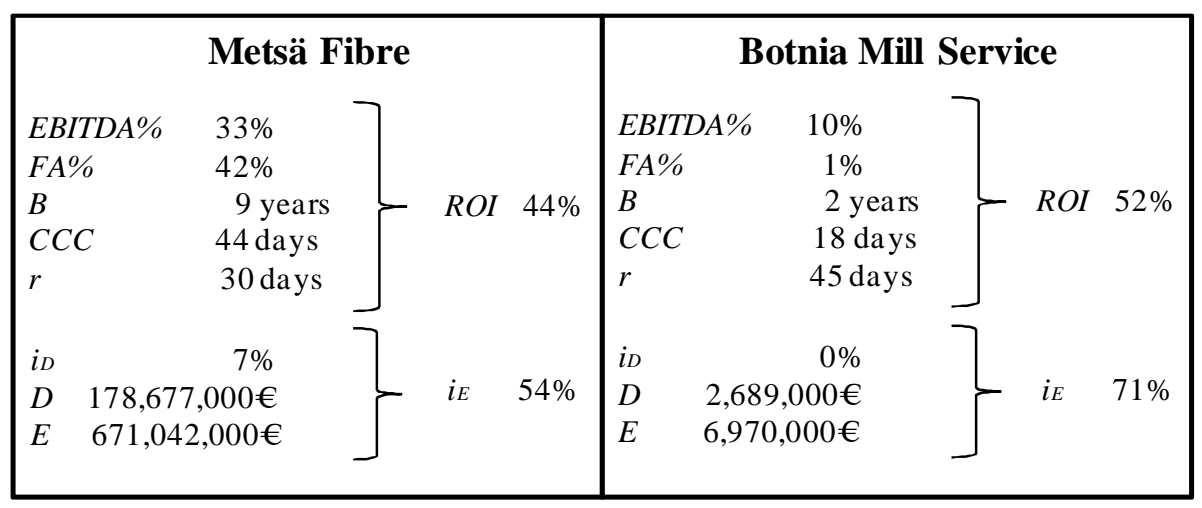

Figure 3 Case company data used in the scenarios

This subsection consists of two scenarios: a scenario of fixed assets and a scenario of working capital. The first scenario is about fixed asset ownership and financial leverage. Let us assume that Botnia Mill Service wishes to transfer a fixed, physical asset of 200,000€ from its balance sheet to the ownership of Metsä Fibre. Thus Botnia Mill Service represents company B discussed in the previous section, and Metsä Fibre stands for company A. Straight-line depreciations of ten years have been hypothesised. Table 1 shows the ROI-levels of the two companies before 
and after the fixed asset transfer, the following change in profitability, and the change in monetary terms. It can be concluded that transferring the fixed asset has profit potential: the profitability of Metsä Fibre would decrease with the extent equivalent to a drop of $1 \mathrm{M} €$ in profits. Botnia Mill Service, on the other hand, would increase its profitability with nearly $2 \mathrm{M} €$. Thus despite the initial losses of Metsä Fibre, there is enough value to be shared to reach a win-win situation. The net benefit is $899,294 €(1,938,492 €-$ $1,039,198 €)$.

Table 1

Scenario on shifting fixed asset ownership

\begin{tabular}{|c|r|r|}
\hline & \multicolumn{1}{|c|}{ Metsä Fibre } & Botnia Mill Service \\
\hline $\boldsymbol{R O I}\left(\boldsymbol{F A} \%_{1}\right)$ & $44.02 \%$ & $51.52 \%$ \\
\hline $\boldsymbol{R O I}\left(\boldsymbol{F A} \boldsymbol{2}_{2}\right)$ & $43.89 \%$ & $71.59 \%$ \\
\hline $\boldsymbol{\Delta R O I}_{\boldsymbol{F A} \%}$ & -0.12 percentage points & 20.07 percentage \\
& & points \\
\hline $\boldsymbol{A R O I}_{\boldsymbol{F A} \%} *(\boldsymbol{D}+\boldsymbol{E})$ & $-1,039,198 €$ & $1,938,492 €$ \\
\hline
\end{tabular}

Now we incorporate financial leverage to the simulation. Table 2 presents the return on equity of Metsä Fibre before and after the transfer of the fixed asset, as well as the change in both percentage points and monetary terms. The two columns show the situation when Metsä Fibre chooses to finance the asset with either debt or equity. It can be seen that the impact of financial leverage must not be neglected: in monetary terms the return on equity of Metsä Fibre would increase by over 70,000€ when using debt financing. Due to the heavy balance sheet of Metsä Fibre, even a small modification in the $\Delta i_{E}$, expressed in percentage points, causes extensive changes in the $\Delta i_{E}{ }^{*} E$, expressed in monetary terms. It would definitely be advisable to finance the fixed asset with debt. Of course, this only holds when the profitability of Metsä Fibre is high enough to enable financial leverage instead of disadvantage.

Table 2

Financial leverage of Metsä Fibre in the fixed asset scenario

\begin{tabular}{|c|r|r|}
\hline & Using debt financing & Using equity financing \\
\hline $\boldsymbol{i}_{\boldsymbol{E} 1}$ & $53.6896 \%$ & $53.6896 \%$ \\
\hline $\boldsymbol{i}_{\boldsymbol{E} 2}$ & $53.7006 \%$ & $53.6867 \%$ \\
\hline $\boldsymbol{\Delta} \boldsymbol{i}_{\boldsymbol{E}}$ & 0.011 percentage points & -0.003 percentage points \\
\hline $\boldsymbol{\Delta \boldsymbol { i } _ { \boldsymbol { E } } * \boldsymbol { E }}$ & $73,585 €$ & $-19,587 €$ \\
\hline
\end{tabular}


Adding up tables 1 and 2, the losses of Metsä Fibre would be 965,613€ $(1,039,198 €-73,585 €)$ after taking financial leverage into account. According to equation (3), this is also the lowest agreeable price to be set for this particular service of asset ownership. On the other hand, the increase in the profitability of Botnia Mill Service equals additional profits of $1,938,492 €$. This is thus the highest agreeable price for the service. The net benefits to be shared between the contracting companies equal the difference between the highest and the lowest agreeable price: 972,879€ $(1,938,492 €-965,613 €)$.

Our second scenario is about working capital management. It involves transferring spare part stocks from one company to another, adjusting payment terms, and using financial leverage in the process. We assume that the spare part stocks and payment terms are transferred in such a way that a sum of 3,300,000€ is taken off from the balance sheet of Botnia Mill Service (company B), and added to the balance sheet of Metsä Fibre (company A). This would change the CCCs of the two companies, and thus also the profitability. Table 3 shows the results of the working capital scenario, concluding that the arrangement would result in a monetary loss of nearly 2,400,000€ for Metsä Fibre, but a monetary benefit of almost 2,600,000€ for Botnia Mill Service. This means that a win-win situation can be created through collaboration. The net benefit equals $212,740 €(2,581,943 €-$ $2,369,203 €)$.

Table 3 Scenario on working capital management

\begin{tabular}{|c|r|r|}
\hline & Metsä Fibre & Botnia Mill Service \\
\hline $\boldsymbol{R O I}\left(\boldsymbol{C C}_{\boldsymbol{1}}\right)$ & $44.02 \%$ & $51.52 \%$ \\
\hline $\boldsymbol{R O I}\left(\boldsymbol{C C}_{2}\right)$ & $43.74 \%$ & $78.25 \%$ \\
\hline $\boldsymbol{\Delta R O \boldsymbol { I } _ { \boldsymbol { C C C } }}$ & -0.28 percentage points & 26.73 percentage \\
& & points \\
\hline$\Delta \boldsymbol{R O I}_{\boldsymbol{C C C}}{ }^{*}(\boldsymbol{D}+\boldsymbol{E})$ & $-2,369,203 €$ & $2,581,943 €$ \\
\hline
\end{tabular}

In table 4, the impact of financial leverage of Metsä Fibre on the contract profitability is presented. The benefit of using debt financing is over 1,200,000€ for Metsä Fibre, which thus improves the profitability of the arrangement substantially. Again, using debt instead of equity is highly advisable. 


\begin{tabular}{|c|r|r|}
\hline & Using debt financing & Using equity financing \\
\hline $\boldsymbol{i}_{\boldsymbol{E} \boldsymbol{1}}$ & $53.49 \%$ & $53.49 \%$ \\
\hline $\boldsymbol{i}_{\boldsymbol{E} 2}$ & $53.67 \%$ & $53.44 \%$ \\
\hline $\boldsymbol{\Delta} \boldsymbol{i}_{\boldsymbol{E}}$ & 0.18 percentage points & -0.05 percentage points \\
\hline $\boldsymbol{\Delta \boldsymbol { i } _ { \boldsymbol { E } } * \boldsymbol { E }}$ & $1,208,985 €$ & $-320,339 €$ \\
\hline
\end{tabular}

After including the impact of financial leverage into the analysis, the losses of Metsä Fibre, expressed in monetary terms, are 1,160,218€ $(2,369,203 €-$ $1,208,985 €)$. According to our logic of value sharing, this is the minimum price to be set for this particular service of owning spare part stocks and adopting the altered payment terms. The benefits for Botnia Mill Service are 2,581,943€, which is also the maximum price for this additional service. The net benefits created through this kind of collaboration equal 1,421,725€ $(2,581,943 €-1,160,218 €)$.

Our scenarios are concluded with figure 4, in which the net benefits are presented for each of the two scenarios before and after taking the impact of financial leverage into account.

Figure 4 Comparing the benefits of the two scenarios of flexible asset management services

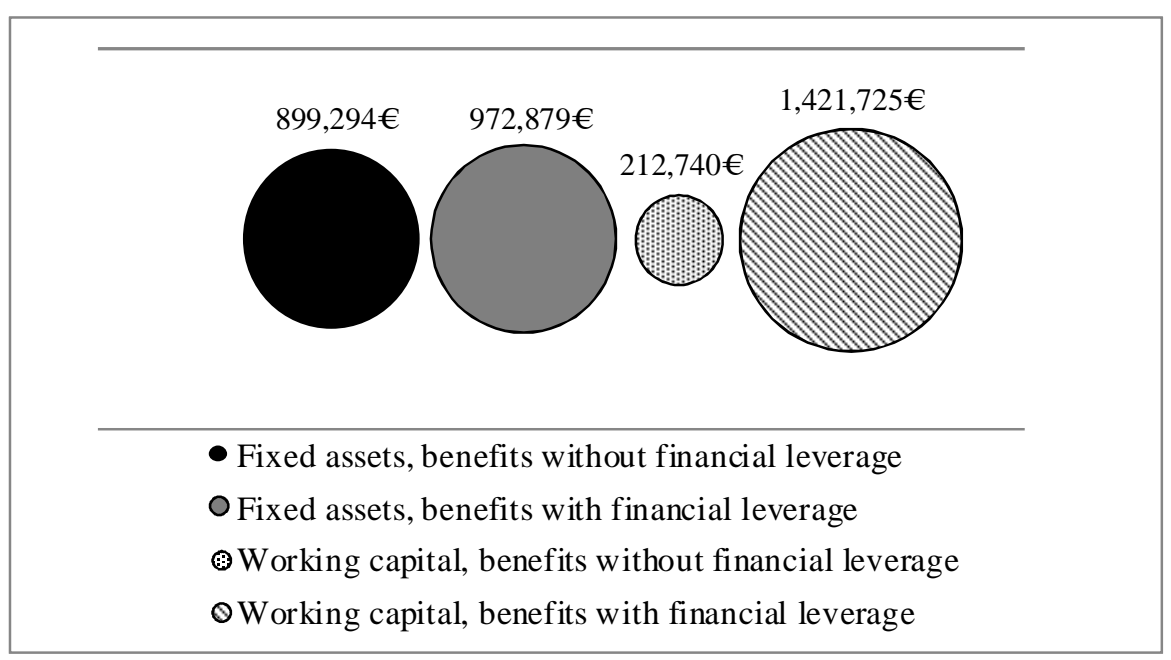


When the impact of financial leverage is taken into account, the working capital management scenario seems more preferable for our case companies. However, the amount of capital to be shifted between the companies has been presumed to be 200,000€ in the fixed asset scenario, and 3,300,000€ in the working capital management scenario. Thus the large amount of capital has increased the role of financial leverage in the working capital scenario. It can be seen in figure 4 that the benefits of the working capital scenario are moderate without the financial leverage, compared with the fixed asset scenario. In fact, if the working capital scenario was conducted with the same amount of capital transferred between the companies than in the fixed asset scenario $(200,000 €)$, an agreeable price would not be found at all. Thus the value of this scenario depends on the large amount of capital to be transferred, which of course increases the risks of the contract.

The fixed asset scenario, on the other hand, shows that including flexible management of fixed assets into the contract can create value even when the amount of capital to be transferred is quite small. The proportional impact of financial leverage is minor.

\subsection{Exploiting flexible asset management contracts}

The lessons learned from the case study are summarised next. Now it is time to examine how different companies can profit from a link between maintenance contracts and flexible asset management. Figure 5 shows a framework of how companies with a light or heavy balance sheet should create asset management collaboration to maximise their relative profitability.

Figure 5 Framework of how different companies should exploit flexible asset management in their maintenance contracts to gain value 


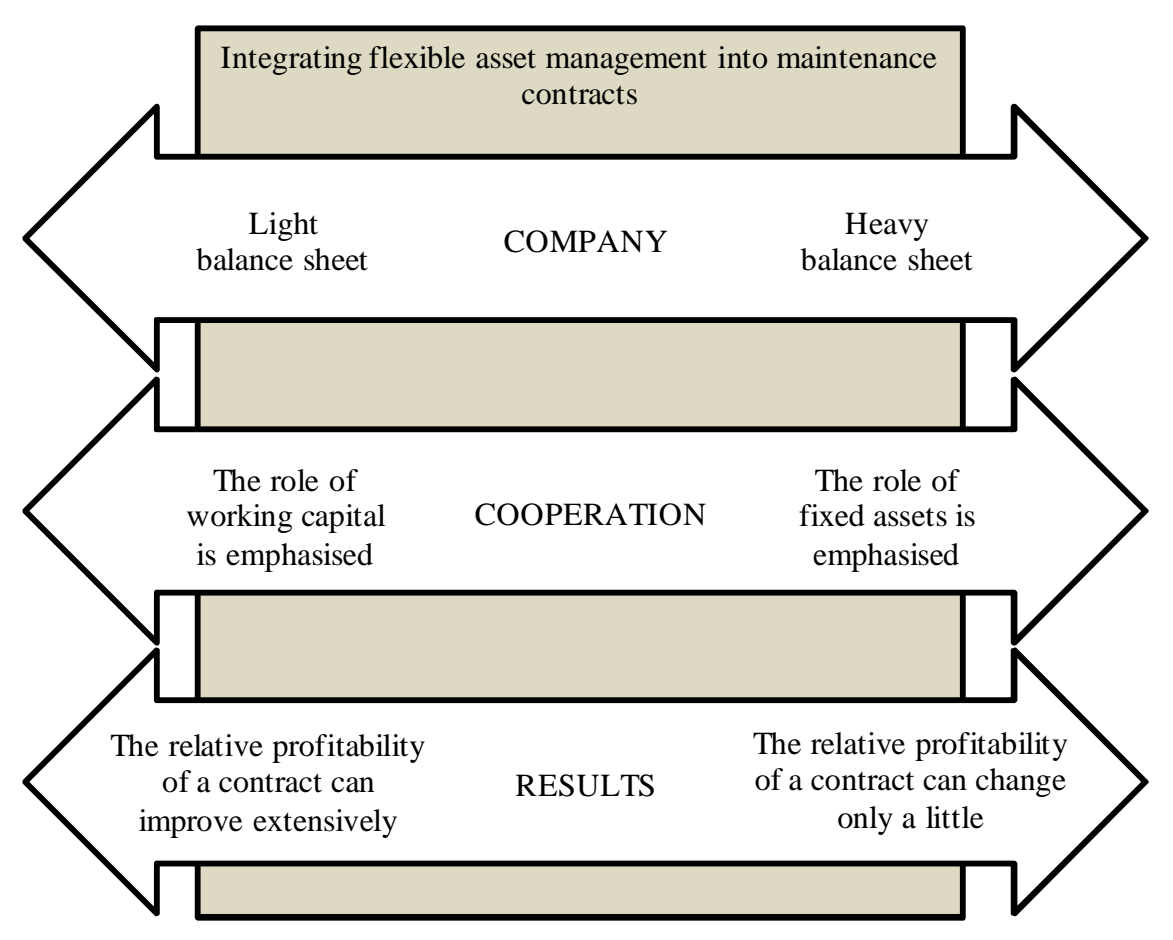

Maintenance service buyers usually carry heavy assets, compared with service providing companies. A specific monetary sum affects the relative profitability of these companies differently. As a result, transferring assets from the balance sheet of a service provider to the balance sheet of a customer creates a lot of additional value. On the other hand, transferring assets from a customer to the light balance sheet of a service provider often destroys value instead of creating it. It would thus be crucial for customer companies to be open-minded to extensive collaboration, instead of just advancing their own benefit in the short term. As we have shown, win-win situations can emerge from applying flexible asset management contracts, despite the ostensible losses incurred for the maintenance customer.

In general, the amount of fixed assets influences the relative profitability more than the amount of working capital. Thus, flexible management of fixed assets should be a priority. However, it needs to be noted that working capital management should not be neglected. Its influence on profitability depends on multiple parameters of a company. 
The role of working capital is emphasised in companies which carry light fixed assets, for example in many service providing companies.

Companies carrying heavy balance sheets need extensive transfers in order to alter their relative profitability either through an actual contract or financial leverage. High-value transfers increase the risks of the contract, and decrease its attractiveness. The impact of these increased risks on the contract profitability should be measured, but this issue is here left for further research.

\section{Conclusions}

We have contributed to the literature by introducing a new maintenance contract type, flexible asset management contracts. Compared to traditional contract types, these contracts have higher potential benefits, and a better potential to create win-win situations. It would be important for maintenance service providers and their customers to utilise these contracts: maintenance collaboration is developing rapidly, but so far the decision makers have lacked tools to manage nontraditional forms of collaboration.

Through proper pricing, flexible asset management contracts can create significant financial benefits for both contracting parties. These contracts consider not just the perspective of customer companies, but also that of service providers. This is quite exceptional, as previous literature has mostly focused on the customer's viewpoint. Instead of analysing the maintenance work itself, we have concentrated on the value sharing of the little studied issues of fixed asset and spare part ownership.

We have learned that compared to working capital management, fixed asset management has a greater impact on profitability. Thus the first step for company managers is to analyse how much value could be created by transferring fixed assets to and from their balance sheets. After that, value creation through working capital management should be addressed.

Our first research limitation is about using financial statement data and creating fictitious scenarios. Not many companies are ready to unveil their experiences with highly collaborative contracts. Thus researching these contracts with authentic case data must be left for further research at the moment. We have also studied the contracts with only one pair of case companies. This was justified, as including more companies would have 
exceeded the scope of the article. Nevertheless, it is important to conduct future research on contracts with a more extensive group of companies. This way, the necessity of the contracts can be truly examined. The final research limitation concerns the scope of this article. Some essential issues were left for further research to keep the scope suitable. These issues include studying the financial leverage of the company extracting an asset from its balance sheet. We suggest that future research should include applying flexible asset management contracts with more than two contracting parties. The maintenance collaboration of today can involve three or more companies, which complicates the logic of value sharing to some extent. Also the higher risks and costs of creating and maintaining flexible asset management contracts, compared with traditional contract types, should be studied further. This way the profitability of these contracts can be estimated more precisely. We emphasise that to prosper in the future, companies should actively search for novel ways of collaborating with their partners.

\section{References}

Ahonen, T., Reunanen, M., Pajari, O., Ojanen, V. and Lanne, M. (2010) 'Maintenance communities - a new model for the networked delivery of maintenance services', International Journal of Business Innovation and Research, Vol. 4 No. 6, pp.560-583.

Aoudia, M., Belmokhtar, O. and Zwingelstein, G. (2008) 'Economic impact of maintenance management ineffectiveness of an oil and gas company', Journal of Quality in Maintenance Engineering, Vol. 14 No. 3, pp.237-261.

Chiou, J., Cheng, L. and Wu, H. (2006) 'The determinants of working capital', The Journal of American Academy of Business, Vol. 1 No. 10, pp.149-155.

de Jong, A. and Smit, K. (2012) 'Collaborative contracts for interorganisational quality systems', Journal of Quality in Maintenance Engineering, Vol. 18 No. 2, pp.171-182. 
Dubois, A. and Araujo, L. (2007) 'Case research in purchasing and supply management: opportunities and challenges', Journal of Purchasing \& Supply Management, Vol. 13 No. 3, pp.170-181.

European Federation of National Maintenance Societies. (2011) Intermediate results of the asset management survey for all national maintenance societies. [online] http://elomake.fi/raportti/efnms_2011_survey (Accessed 18 July 2012).

Fantazy, K.A., Kumar, V. and Kumar, U. (2011) 'The impact of information sharing on supply chain performance: an empirical study', International Journal of Procurement Management, Vol. 4 No. 3, pp.274-296.

Gibson, V. (2000) 'Property portfolio dynamics: the flexible management of inflexible assets', Facilities, Vol. 18 No. 3, pp.150-154.

Grosse-Ruyken, P.T., Wagner, S. and Jönke, R. (2011) 'What is the right cash conversion cycle for your supply chain?', International Journal of Services and Operations Management, Vol. 10 No. 1, pp.13-29.

Grossman, S. and Hart, O. (1983) 'An analysis of the principal-agent problem', Econometrica, Vol. 51 No. 1, pp.7-45.

Hart, O. and Holmström, B. (1987) 'The theory of contracts. Part I', in Bewley, T. (Ed.), Advances in Economic Theory, Fifth World Congress, Cambridge University Press, Cambridge, pp.71-155.

Holmström, J., Brax, S. and Ala-Risku, T. (2010) 'Comparing providercustomer constellations of visibility-based service', Journal of Service Management, Vol. 21 No. 5, pp.675-692.

Hui, E. and Tsang, A. (2006) 'The inter-organizational relationship in a multi-contractor business network', Journal of Quality in Maintenance Engineering, Vol. 12 No. 3, pp.252-266. 
Jackson, C. and Pascual, R. (2008) 'Optimal maintenance service contract negotiation with aging equipment', European Journal of Operational Research, Vol. 189 No. 2, pp.387-398.

Komonen, K. (2010) 'Asset management in the industrial sector: background and conceptual approach', Maintworld, Vol. 2 No. 1, pp.16-19.

Kroes, J. and Ghosh, S. (2009) 'A framework and scale development for assessing supply chain outsourcing alignment with competitive priorities', International Journal of Procurement Management, Vol. 2 No. 1, pp.1-24.

Kärri, T. (2007) Timing of capacity change: models for capital intensive industry. Dissertation for the degree of Doctor of Science (Tech.), Lappeenranta University of Technology, Lappeenranta, Finland.

Levery, M. (1998) 'Outsourcing maintenance - a question of strategy', Engineering Management Journal, Vol. 8 No. 1, pp.34-40.

Lin, S., Jing, G., Koronios, A. and Chanana, V. (2007) 'Developing a data quality framework for asset management in engineering organisations', International Journal of Information Quality, Vol. 1 No. 1, pp.100126.

MacCarthy, B.L. and Jayarathne, P.G.S.A. (2012) 'Sustainable collaborative supply networks in the international clothing industry: a comparative analysis of two retailers', Production Planning \& Control, Vol. 23 No. 4, pp.252-268.

Magnan, G.M., Fawcett, A.M. and Fawcett, S.E. (2011) 'Supply chain success: key initiatives differentiating high- and low-performing firms', International Journal of Procurement Management, Vol. 4 No. 2, pp.181-202. 
Markeset, T. and Kumar, U. (2005) 'Product support strategy: conventional versus functional products', Journal of Quality in Maintenance Engineering, Vol. 11 No. 1, pp.53-67.

Martin, H.H. (1997) 'Contracting out maintenance and a plan for future research', Journal of Quality in Maintenance Engineering, Vol. 3 No. 2, pp.81-90.

Marttonen, S., Viskari, S. and Kärri, T. (2011) 'Modeling the impact of working capital management on the profitability in industrial maintenance business'. Paper Presented at the 6th Annual World Congress on Engineering Asset Management (WCEAM). 2-5 October 2011. Cincinnati, USA.

Marttonen, S., Viskari, S. and Kärri, T. (2012) 'Connecting the managerial and owner's view of flexible asset management in industrial maintenance companies'. Paper Presented at the 17th International Working Seminar on Production Economics. 20-24 February 2012. Innsbruck, Austria.

More, D. and Babu, A.S. (2011) 'Managing supply chain flexibility using an integrated approach of classifying, structuring and impact assessment', International Journal of Services and Operations Management, Vol. 8 No. 1, pp.46-75.

Navarro, P. (2009) 'Recession-proofing your organization', MIT Sloan Management Review, Vol. 50 No. 3, pp.45-51.

Ojanen, V., Hatinen, L., Kärri, T., Kässi, T. and Tuominen, M. (2012) 'Flexible investment planning and collaborative maintenance management', in Van der Lei, T. et al (Eds.), The state of the art in Europe from a life cycle perspective, Springer, Dordrecht, pp.65-77.

Panesar, S.S. and Markeset, T. (2008) 'Industrial service innovation through improved contractual relationship', Journal of Quality in Maintenance Engineering, Vol. 14 No. 3, pp.290-305. 
Pongpech, J., Murthy, D.N.P. and Boondiskulchock, R. (2006) 'Maintenance strategies for used equipment under lease', Journal of Quality in Maintenance Engineering, Vol. 12 No. 1, pp.52-67.

Protopappa-Sieke, M. and Seifert, R. (2011) 'Interrelating operational and financial performance measurements in a multiproduct inventory system', International Journal of Services and Operations Management, Vol. 10 No. 3, pp.328-347.

Randall, W.S. and Farris II, M.T. (2009) 'Supply chain financing: using cash-to-cash variables to strengthen the supply chain', International Journal of Physical Distribution and Logistics Management, Vol. 39 No. 8, pp.669-689.

Raut, R.D., Bhasin, H.V. and Kamble, S.S. (2012) 'Analysing the effect of uncertain environmental factors on supplier-buyer strategic partnership (SBSP) by using structural equation model (SEM)', International Journal of Procurement Management, Vol. 5 No. 2, pp.202-228.

Sawhney, R., Kannan, S. and Li, X. (2009) 'Developing a value stream map to evaluate breakdown maintenance operations', International Journal of Industrial and Systems Engineering, Vol. 4 No. 3, pp.229-240.

Talha, M., Christopher, S.B. and Kamalavalli, A.L. (2010) 'Sensitivity of profitability to working capital management: a study of Indian corporate hospitals', International Journal of Managerial and Financial Accounting, Vol. 2 No. 3, pp.213-227.

Tam, A. and Price, J. (2008) 'A maintenance prioritization approach to maximise return on investment subject to time and budget constraints', Journal of Quality in Maintenance Engineering, Vol. 14 No. 3, pp.272289. 
Teece, D.J. (1988) 'Capturing value from technological innovation: integration, strategic partnering, and licensing decisions', Interfaces, Vol. 18 No. 3, pp.46-61.

Vining, A. and Globerman, S. (1999) 'A conceptual framework for understanding the outsourcing decision', European Management Journal, Vol. 17 No. 6, pp.645-654.

Viskari, S., Lukkari, E. and Kärri, T. (2011) 'State of working capital management research: bibliometric study', Middle Eastern Finance and Economics, Vol. 5 No. 14, pp.99-108.

Wang, W. (2010) 'A model for maintenance service contract design, negotiation and optimization', European Journal of Operational Research, Vol. 201 No. 1, pp.239-246.

Yazici, H. (2012) 'Buyer perceptions on the buyer-supplier collaborative relationship and performance: a service example', International Journal of Services and Operations Management, Vol. 12 No. 2, pp.165-187.

Yin, R.K. (2009) Case study research - design and methods, $4^{\text {th }}$ ed., Sage publications, Thousand Oaks. 